\title{
Molecular evidence for Mycobacterium bovis infection in wild Chilean hawk (Accipiter chilensis)
}

\author{
Manuel Moroni ${ }^{\mathbf{a}^{*}}$, Miguel Salgado ${ }^{\mathrm{b}}$, Alejandro Albornoz ${ }^{\mathrm{b}}$, \\ Carlos Tejeda ${ }^{\mathrm{b}}$, Mario Alvarado-Rybak ${ }^{\mathrm{c}}$
}

\begin{abstract}
The present study reports a case of tuberculosis in a juvenile Chilean hawk (Accipiter chilensis). Granulomas were identified in the liver, intestine and mesentery. Several of these granulomas contained acid-fast bacilli suggesting a mycobacterial infection through ingestion. Molecular diagnosis detected Mycobacterium bovis as etiological agent. Whether M. bovis infection in this Chilean hawk represents a risk for other wildlife, livestock or humans remains to be determined.

Key words: Chilean hawk, infection, Mycobacterium bovis, spillover.
\end{abstract}

Mycobacterium bovis (M. bovis), a slow-growing and an obligate intracellular bacterium, produces a chronic infection principally of the respiratory system (Michel et al 2010) affecting most domestic mammals, wild species and humans (Neill et al 2005), and is transmitted via air but also through the digestive tract (Kaneene and Pfeiffer 2006). An important aspect is that $M$. bovis is considered a major zoonotic agent, associated with human tuberculosis (Neill et al 2005).

Transmission of $M$. bovis from domestic animals to wildlife (spillover) and vice versa (spillback) has been facilitated by anthropogenic factors, which have been considered in $M$. bovis infection eradication programs worldwide (Nugent et al 2012).

Avian mycobacterial infection is an ubiquitous disease in domestic, captive, and wild birds caused by $M$. avium complex and M. genavense. Diseases of birds of prey kept in captivity as well as free-living raptors are well documented (Millán et al 2010, Vidal et al 2017). Serological studies show that free-living birds are exposed to pathogens through contact with poultry waste and run-off from farms, or by ingestion of contaminated carcasses (Höfle et al 2002, Cunha et al 2017), first being susceptible hosts, thereafter potential sources of the infection. The aim of the present study was to provide evidence of $M$. bovis infection in a wild Chilean hawk specimen found dead in southern Chile, where the major part of the Chilean livestock production system is situated.

According to phenotypic features (Pavez 2004), a juvenil Accipiter chilensis (order Accipitriformes), commonly known as Chilean hawk, was found dead in a rural area

\footnotetext{
Accepted. 20.03.2018

anstituto de Patología Animal, Facultad de Ciencias Veterinarias, Universidad Austral de Chile, Valdivia, Chile.

bInstituto de Medicina Preventiva Veterinaria, Facultad de Ciencias Veterinarias, Universidad Austral de Chile, Valdivia, Chile.

${ }^{\mathrm{c} C e n t r o ~ d e ~ I n v e s t i g a c i o ́ n ~ p a r a ~ l a ~ S u s t e n t a b i l i d a d ~ y ~ P r o g r a m a ~ d e ~ D o c t o-~}$ rado en Medicina de la Conservación, Facultad de Ciencias de la Vida, Universidad Andres Bello, Santiago, Chile.

*Corresponding author: M Moroni; Los Laureles s/n, Edificio Federico Saelzer, 3er piso, Campus Isla Teja, Valdivia, Chile; manuelmoroni@uach.cl.
}

near the city of Valdivia, Chile $\left(39^{\circ} 48^{\prime} \mathrm{S}, 73^{\circ} 15^{\prime} \mathrm{W}\right)$. The animal was submitted to Universidad Austral de Chile for further analysis. A complete necropsy was performed. The bird showed little subcutaneous and intracoelomic fat. Multiple nodules of approximately $2-5 \mathrm{~mm}$ diameter, whitish in color and of firm consistency, were observed on the surface and inside the liver parenchyma, as well as in the mesentery and wall of the small intestine (figure 1A). Multiple sections of small intestine and liver were fixed in $10 \%$ neutral buffered formalin and embedded in paraffin, sectioned at $5 \mu \mathrm{m}$, and stained with hematoxylin and eosin (HE) and Ziehl-Neelsen (ZN) stain. The liver and the intestinal submucosa showed multiple granulomas with central necrosis, surrounded by histiocytic infiltrate with presence of multiple giant cells and few heterophils (figure 1B). The $\mathrm{ZN}$ stain showed large numbers of red acid-fast bacilli (AFB) on the inside and in the periphery of the granulomas (figure 1C). Two paraffin blocks containing hepatic tissue and tissue from the small intestine wall were selected for molecular confirmation. To prevent cross contamination of the samples for PCR, the microtome and each paraffin block were disinfected with a $10 \%$ chlorine solution and thereafter with $100 \%$ ethanol between cuts and before inserting a new block into the microtome. Ten to twenty sections measuring $5 \mu \mathrm{m}$ were cut and transferred into a sterile $1.5 \mathrm{~mL}$ tube for paraffin removal (Miller et al 1997). After the dewaxing process of the embedded specimen, the samples were subjected to DNA extraction, PCR confirmation and molecular typing. The High Pure PCR Template Preparation kit (Roche) was used as DNA extraction-purification protocol, following the manufacturer instructions. A real-time PCR system was used to confirm suspected infectious agents. Primarily, the insertion element IS901 sequence was used as target for Mycobacterium avium subsp. avium (Maa) (Pradenas et al 2014). Secondly, a real-time TaqMan PCR was used to target a specific for the $65-\mathrm{kD}$ heat shock protein gene from M. genavense and MAC organisms (Tell et al 2001). Thirdly, a real-time PCR to identify $M$. bovis species was performed using a published protocol (Sweney et al 2007), specific for the RD4 genomic region. 


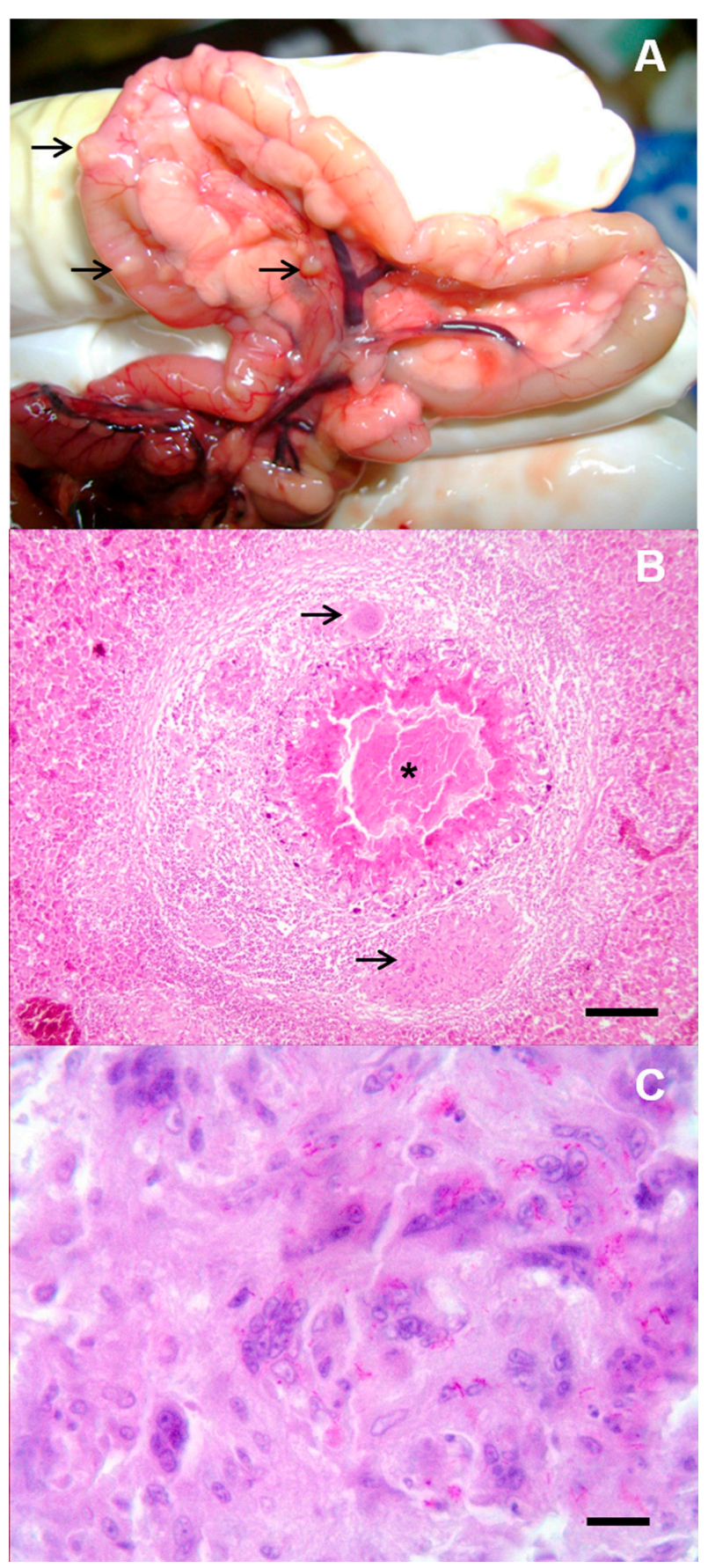

Figure 1. Accipiter chilensis tuberculosis granulomas. A: intestine and mesenterium with multiple granulomas $(\rightarrow)$. B: granuloma with central necrosis $(*)$, histiocytic cell infiltration and giant cells $(\rightarrow)$ in liver parenchyma (HE, 100x, Barr=100 $\mu \mathrm{m})$. C: Ziehl Neelsen staining revealed multiple acid-fast bacilli in the cytoplasm of multinucleated giant cells (ZN, 1000x, Barr=10 $\mu \mathrm{m})$.

All samples from the granuloma lesions with AFB in the affected tissue that were submitted to molecular confirmation resulted positive only for $M$. bovis and negative for Maa and M. genavense. To refine our understanding of the presence of $M$. bovis in the affected tissue, locus-specific PCR primer sets were used to amplify nine tandem repeats (TRs) from within the genomic DNA of M. bovis. The target loci included two exact tandem repeats (ETR A and C), six mycobacterial interspersed repetitive-units (MIRU 2, 10, 20, 23, 26, 39) and one Queen's University of Belfast (Qub23) (Supply 2006). PCR amplicons were analysed by fragment analyser capillary electrophoresis system (Labgene Scientific SA). The electrophoretogram showed a VNTR code 7-5-2-5-2-4-7-1-6, in agreement with M. bovis ETR-A, ETR-C, MIRU 2, 10, 20, 23, 26, 39 and QUB23 loci, respectively (table 1). The presence of MIRU 10 with two repetitions instead of five and of MIRU 26 with seven repetitions instead of two to six identified a new M. bovis VNTR pattern. The electrophoretogram picks for the two mentioned VNTRs were clearly defined.

The Chilean hawk is a raptor living exclusively in the southern temperate forests of Chile and Argentina $\left(33^{\circ}-56^{\circ}\right.$ S) (Figueroa et al 2004). The bird is well adapted to this environment, feeding mainly on birds, a few rodents and insects (Trejo et al 2006). This hawk species is included in Appendix II of the Convention on International Trade in Endangered Species of Wild Fauna and Flora, CITES.

The present study reports lesions consistent with tuberculosis and $M$. bovis detection and confirmation in a dead Chilean hawk. The latter represents an uncommon finding, since avian mycobacterial infections are mainly associated with M. avium, although a few other mycobacterial species have been identified (Steele 1995). The PCR negative results regarding no Maa and $M$. genavense detection, provide more supportive evidence that Mycobacterium bovis was the bacteria causing the lesions, and assure that there was no cross reaction with avian mycobacterial pathogens that can cause similar granulomatous lesions.

Mycobacterial infections in wild birds are difficult to detect and usually have a low prevalence, causing clinical disease only in a few cases (Tell et al 2001, Sánchez et al 2016).

Moreover, clinical manifestations in wildlife are rarely found, and are usually identified only if a necropsy is performed (Hoop et al 1996), as was the case in the present study. Typical tuberculosis granulomas were identified from the liver, intestines and mesentery of the hawk and several of these granulomas contained acid-fast bacilli, suggesting an infection transmission by ingestion. The latter becomes an acceptable hypothesis, as Chilean hawk has experienced a decrease in the amount of prey species dwelling within the temperate native forest, which has been fragmented due to farming activities (Jaksic and Jiménez 1986). First, the hunting and consumption of infected rodents or birds and maybe scavenging behaviour of infected ruminants in farming grassland areas could therefore explain the present finding. In the area where the hawk was found dead, a bovine tuberculosis eradication program is currently underway and under control. However, high rates of infection in some areas and in some medium sized to large herds still remain (Max et al 2011). 
Table 1. Number of copies of M. bovis VNTR for the nine loci analysed.

\begin{tabular}{|c|c|c|c|c|c|c|c|c|c|}
\hline & \multicolumn{2}{|c|}{ ETR } & \multicolumn{6}{|c|}{ MIRU } & \multirow{2}{*}{$\frac{\text { QUB }}{23}$} \\
\hline & A & $\mathrm{C}$ & 2 & 10 & 20 & 23 & 26 & 39 & \\
\hline Amplicons base pair & 719 & 318 & 504 & 731 & 589 & 347 & 637 & 578 & 161 \\
\hline $\mathrm{N}^{\circ}$ repetitions & 7 & 5 & 2 & 5 & 2 & 4 & 7 & 1 & 6 \\
\hline
\end{tabular}

ETR: exact tandem repeats.

MIRU: Mycobacterial Interspersed Repetitive Units.

QUB: Queen's University of Belfast.

The real-time PCR systems to confirm suspected infectious agents used specific probes and primers. Besides, the protocol considered a negative and positive controls in order to surveillance the proficiency of the reaction as well as DNA extraction negative and positive controls. Therefore, the odds of false-positive results were not expected. The typing information correlates with a $M$. bovis VNTR genotype with a SB0140 spoligotype, the most commonly found genotype in cattle in southern Chile (Zumárraga et al 2013). This report expands the diversity of wildlife species that can become actively infected by M. bovis. Whether M. bovis infection in this Chilean hawk represents a risk of infection for livestock, humans or just a dead end host, remains to be determined.

\section{ACKNOWLEDGEMENTS}

The authors would like to thank Sofía Egaña and Alejandro Aleuy for presenting the case to the Institute of Animal Pathology.

\section{REFERENCES}

Cunha M, Azorín B, Peñuela R, Albuquerque T, Botelho A. 2017 Exposure of threatened Accipitridae to Mycobacterium bovis calls for active surveillance. EcoHealth 14, 310-317.

Figueroa R, Alvarado S, Bravo C, Corales S, González B, et al. 2004. Características de las presas del Peuquito (Accipiter chilensis) en el bosque templado austral. Hornero 19, 77-82.

Höfle U, Blanco JM, Kaleta EF. 2002. Seroprevalence of avian paramyxovirus 2, and 3 in captive and free-living birds of prey in Spain (preliminary results): implications for management of wild and captive populations. Ann N Y Acad Sci 969, 213-216.

Hoop R, Bottger E, Pfyffer G. 1996. Etiological agents of Mycobacterioses in pet birds between 1986 and 1995. J Clin Microbiol 34, 991-992.

Jaksic FM, Jiménez JE. 1986. The conservation status of raptors in Chile. Birds of Prey Bull 3, 95-104.

Kaneene JB, Pfeiffer D. 2006. Epidemiology of Mycobacterium bovis. In: Thoen CO, Steele JH, Gilsdorf MJ (eds). Mycobacterium bovis infection in animals and humans. Blackwell, Oxford, UK, Pp 34.
Max V, Paredes L, Rivera A, Ternicier C. 2011. National control and eradication program of bovine tuberculosis in Chile. Vet Microbiol 151, 188-191.

Michel AL, Müller B, van Helden P. 2010. Mycobacterium bovis at the animal-human interface: A problem, or not? Vet Microbiol 140, $371-381$.

Millán J, Negre N, Castellanos E, de Juan L, Mateos A, et al. 2010. Avian mycobacteriosis in free-living raptors in Majorca Island, Spain. Avian Pathol 39, 1-6.

Miller J, Jenny A, Rhyan J, Saari D, Suarez D. 1997. Detection of Mycobacterium bovis in formalin fixed, paraffin-embedded tissues of cattle and elk by PCR amplification of an IS6110 sequence specific for Mycobacterium tuberculosis complex organisms. J Vet Diagn Invest 9, 244-249.

Neill SD, Skuce RA, Pollock JM. 2005. Tuberculosis-new light from an old window. J Appl Microbiol 98, 1261-1269.

Nugent G, Whitford J, Yockney IJ. 2012. Reduced spillover transmission of Mycobacterium bovis to feral pigs (Sus scrofa) following population control of brushtail possums (Trichosurus vulpecula). Epidemiol Infect 140, 1036-1047.

Pavez E. 2004. Descripción de las aves rapaces chilenas. In: MuñozPedreros A, Rau J, Yañez J (eds). Aves Rapaces de Chile. CEA Ediciones, Valdivia, Chile, Pp 29-103.

Sánchez F, Yela I, Alfonseca E, Campuzano J, Morales E, et al. 2016. Respiratory tract infection caused by Mycobacterium bovis in a black swan (Cygnus atratus). Avian Pathol 45, 126-31.

Steele JH. 1995. Regional and country status reports. Thoen CO, Steele JH (eds). In: Mycobacterium bovis infection in animals and humans. Iowa State University Press, Ames, Iowa, USA, Pp 169-172.

Supply P. 2006. Proposal for standardization of optimized mycobacterial interspersed repetitive unit-variable-number tandem repeat typing of Mycobacterium tuberculosis. Clinical Microbiol 44, 4498-4510.

Tell L, Woods L, Cromie R. 2001. Mycobacteriosis in Birds. Rev Sci Tech OIE 20, 180-203.

Trejo A, Figueroa RA, Alvarado S. 2006. Forest-specialist raptors of the temperate forests of southern South America: a review. Rev Bras Ornitol 14, 317-330.

Vidal A, Baldomà L, Molina-López R, Martin M, Darwich L. 2017. Microbiological diagnosis and antimicrobial sensitivity profiles in diseased free-living raptors. Avian Pathol 46, 442-450.

Zumárraga M, Arriaga C, Barandiaran S, Cobos-Marín L, de Waard J, et al. 2013. Understanding the relationship between Mycobacterium bovis spoligotypes from cattle in Latin American Countries. Res Vet Sci 94, 9-21. 
